\title{
The Conceptual Development of In-service EFL Teachers' Perception of Grammatical Mediation on Three Planes: A Sociocultural Perspective
}

\author{
Saman Ebadi \\ Assistant Professor of Applied Linguistics, \\ Razi University, Kermanshah, Iran \\ Nouzar Gheisari* \\ PhD Candidate of TEFL, \\ Razi University, Kermanshah, Iran
}

Received 4 March 2015; revised 2 August 2015; accepted 25 August 2015

\begin{abstract}
The present study, following Vygotskyan Sociocultural theory in education, and inspired by Rogoff's conceptualization $(1995,2003)$ of development, aimed at conceptual development of in-service EFL teachers. To this end, two Iranian EFL teachers with pseudonyms (Tara and Sara) were selected as participants of the study. The participating teachers were first taught the sociocultural concepts related to language, teaching, and learning taken from Johnson (2009) and Rogoff's (2003) mediatory model of development in six workshops through dialogic mediation. The data for the study comprised two semi-structured interviews, and three video-recording of critical reflection of each teacher on their video-taped classroom behavior. The recordings and transcripts were analyzed using Hatch's (2002) procedure for interpretive analysis. The results of the study showed that participating teachers, over a process of struggle with *Corresponding author: English Department, Razi University, Kermanshah, Iran.

Email address: nouzargheisari@yahoo.com
\end{abstract}


their past experiences, gradually replaced their old everyday concepts such as grammatical accuracy, correct samples, and teacher interruption with new scientific concepts such as grammatical apprenticeship, guided grammatical participation, and grammatical appropriation through assisted participation. The results of present study can be illuminating for teacher educators and teacher education programs which have aimed at changing the classroom practice of inservice teachers.

Keywords: Awareness-raising; Critical reflection; Sociocultural teacher education; Mediation; Conceptual development

\section{Introduction}

Teacher professional development is the key to improving the quality of student learning, which is all that any educational enterprise is striving for (Grimmett, 2014; Johnson, 2009; Johnson \& Golombek, 2011). However, teachers in second language education programs bring with them their experiences as language learners (Lortie, 1975), and these previous experiences shape their views of language and language teaching (Grimmett, 2014; Johnson, 2006, 2009; Johnson \& Golombek, 2011), albeit they might not result in shaping an engaging classroom interactional architecture( Seedhouse, 2004) which benefits the language learners. Also, inspired by tenets of positivistic research in education, it is clear that prior experiences of language learners - particularly in formal settings - has led to the view that language is, in essence, a set of grammatical rules, lexical items, and four skills (Johnson, 2009). Based on the findings from such positivistic epistemology, many second language educational textbooks, courses and teacher pre-service and in-service programs have been organized internationally.

This atomistic view of language that seems to have configured the content of L2 teacher education programs, however, may not provide teachers with a conceptualization of language that is amenable or useful for L2 instruction (Walsh, 2011). Also, as Freeman (2004) and Johnson, $(2006,2009)$ put it, the disciplinary knowledge that defines what language is, how it works, and how it is acquired that has emerged out of the fields of theoretical linguistics and SLA is not the same knowledge that teachers need to teach L2, nor is it the same knowledge that students need in order to learn their L2. 
However, as a result of the social turn in applied linguistics (Block, 2003), and increasing interest in a sociocultural theoretical perspective in second language teacher education (Grimmett, 2014; Johnson, 2006, 2009; Johnson \& Golombek, 2011), new theoretical concepts have offered the potential to broaden notions of language and what it means to be a language teacher. This, in turn, is the consequence of interpretive epistemological perspective in research (Johnson, 2009). This perspective, drawn largely from ethnographic research in sociology and anthropology, and in stark contrast with positivist research paradigm, began to establish itself in educational research during 1970s (Stenhouse, 1975). This research epistemology, in educational research, necessitated a shift from observational studies of what teachers do to ethnographic descriptions based on observation, description, and interviews with teachers about why they do what they do (Johnson, 2009). Therefore, instead of mental verbalism of emerged concepts in the field and predicting what teachers should do, interpretative research, through verbalizing what teachers already know and penetrating into their mental life (Freeman, 2002; Walberg, 1977), can lay the foundation for their professional development by appropriation of related concepts through guiding participants, reconceptualizing their views on language, teaching, and learning, transforming their practice and re-contextualizing the microstructures of the classroom context within which they enact their teaching practices.

In theory, this can be seen as a way out of the misconceptions related to learning-teaching notions which L2 teachers have inherited from their own instructional histories as learners (Lortie, 1975). Not taking care of conceptual development of L2 teachers causes them to start the profession with largely unarticulated, yet deeply ingrained, notions about what language is, how it is learned, and how it should be taught (Freeman, 2002). That is the kind of unconscious empirical learning that may result in misconceptions about language learning and teaching (Johnson \& Golombek, 2011, 2015).

From an experiential point of view, the main reason behind conducting the present study was two-fold. First, more than 15 years of professional life of one of the researchers in Language Teaching Institutes both as a teacher and supervisor granted him the insight that, despite claims regarding the communicative teaching of grammar, great majority of English teachers resorted to the already-ingrained explicit instruction of grammatical structures which in most cases resulted in 
teaching about the L2 than the L2. Second, the two participating teachers, who had been working under the supervision of one of the researchers during their professional life, always expressed dissatisfaction over their grammar teaching moments in supervising sessions and friendly meetings, claiming that there is always communication breakdowns in their classes, when they start teaching grammar.

To this end, the present study, framed in general within tenets of Vygotskian sociocultural theory regarding the importance of scientific concepts in learning, aimed at conceptual development of two Iranian EFL teachers regarding teaching grammar by giving awareness of and critical reflection on the teachers' classroom interaction. Theoretically, the study also benefited from the underpinnings of the model proposed by Rogoff's $(1995,2003)$ mediation in three planes of apprenticeship, wherein community models are provided to the novice; guided participation, which occurs through joint activity by expert and novice; and participatory appropriation, where the novice uses the tool without social mediation. According to Rogoff, any type of development, including grammatical development, occurs in three planes of analysis corresponding to personal, interpersonal, and community processes. That is, first, the expert mediates the learners personally, then the learners mediate each other by supervision and guidance of the expert, and finally, the learners apply the appropriated materials in new contexts of the community.

In a nutshell, the study's main objective was the conceptual development of the teachers regarding how to view and teach grammar based on Vygotsky's Sociocultural theory and the three developmental planes of apprenticeship or personal help, guided participation, and participatory appropriation adopted from Rogoff's model by replacing the teachers' everyday concepts of teaching grammar through re-conceptualizing their concepts and re-contextualizing their practice. For this to happen, according to Grimmet (2014), Johnson \& Golombek, (2011, 2015), Vygotsky, $(1978,1987)$, the everyday concepts of teachers must be replaced with related scientific ones through dialogic mediation. The re-conceptualization of the teachers is believed to result in re-contextualizing their professional practice, which consequently results in change in the participatory structure of the English classes (Johnson, 2009; Johnson \& Golombek, 2011). Also, according to Walsh, for replacing of unconsciously ingrained everyday concepts with scientific ones, raising teacher's consciousness of their present thinking and behavior by 
penetrating into their mental life, and persistent critical reflection on their emerging practices seems to be most effective (Walsh, 2011). To fulfill this, the study first aimed at eliciting present thinking of teachers regarding grammar, grammar teaching and learning, and then conceptual development of the teachers based on sociocultural concepts regarding how to teach grammar through awareness-raising of and critical reflection on their ongoing thinking and practice. So, the study was designed to answer the following questions.

1. How do participating teachers perceive grammar and grammar teaching before their conceptual development intervention?

2. Does the experience of awareness-raising through critical reflection on two EF teachers' grammar classes change their conceptual thinking of grammar and grammar teaching?

\section{Review of the Related Literature}

The present research theoretically adheres to the underpinnings of situated theories to learning (Lave \& Wenger, 1991; Leontev 1981; Rogoff, 1995, 2003) which are in essence rooted in the underlying principles of Sociocultural theory (Vygotsky, 1978) which sees leaning as situated in a social environment created by a particular community of practice. Such theories relate to the underpinnings of constructivist epistemology which states that people learn actively, rather than passively, and construct their knowledge through active participation in institutional, social, and individual contexts. The present study is theoretically linked to three theories of situated learning: the approach to sociocultural analysis developed by Rogoff (1995), Leontev's (1981) cultural historical activity theory, and legitimate peripheral participation within a community of practice (Lave \& Wenger, 1991).

\section{Concept development}

Research suggests that teachers with constant practice experience, alongside academic study, benefit from the ability to relate theoretical concepts to real teaching situations (Darling-Hammond, 2006; Ord, 2010). However, the major challenge is that cultures and practices of early life and in school years unconsciously configure the teacher's practice (Lortie, 1975; Nutlle, 2005). 
Moreover, according to Vygotsky (1987), the most effective strategy for improving second language teacher education is concept development the way it has been understood within the overall framework of sociocultural theory for two main reasons. First, it provides a rational for including a formal, theoretical learning component to teacher education programs as opposed to learning only through practical classroom experience since developing scientific concepts, based on Vygotsky, makes the teachers think in concrete ways in concepts they have already developed.

Second, sociocultural accounts of concept development provide a framework that unifies theoretical and practical knowledge in teacher education which has been referred to as persistence divide between pedagogy and practice within the framework of positivistic accounts to teacher development (Johnson, 2009). In fact, bridging theory and practice has been one of the most persistent problems in the field of teacher education for as long as the history of teacher education (Britzman, 1991; Grimmett, 2009; Kennedy, 1999). Adhering to micro-genetic development of already-emerged theoretical concepts in the field of ELT through giving awareness of teachers' present practices and critical reflection on what they do, teachers can better re-conceptualize their attitudes towards teaching, thereby leading to re-contextualizing their teaching practices in the local context of the classroom (Walsh, 2011).

\section{Conceptual development of grammatical mediation on three inter-related planes}

Following Block's (2003) coinage of the term "social turn in second language acquisition", which emphasizes social nature of learning, proponents of sociocultural theory to teacher education believe that re-conceptualizing teachers' thinking and re-contextualizing their teaching practice urges development of scientific concepts in a way that they become concrete psychological tools in the commands of the teachers for critical moments of decision making. That is, they get accustomed to institutional practice (Grimmet, 2014) of those concepts. Also, as pointed to earlier, Rogoff (1995, 2003) believes that any sociocultural activity must be observed on three planes of development if it is to result in transformation of practice. These planes are apprenticeship, guided participation, and participatory appropriation. 
In the apprenticeship phase of development, newcomers to the new community of practice advance their skill and understanding through participation with expert others in culturally organized activities (Bruner, 1983; Dewey, 1916; Goody, 1989; Lave \& Wenger, 1991; Rogoff, 1990). Applied to the mini-context of the classroom, the apprenticeship phase of development makes participants ready for peripheral participation by providing them with structural practices which are going to be used in their follow-up participations.

In the guided participation phase, the mutual involvement of individuals and their social partners is emphasized. During this phase, the novices communicate and coordinate their involvement as they participate in socio-culturally structured collective activity while they receive appropriate help from the expert (Rogoff, 1990; Rogoff \& Gardner, 1984).

In the appropriation, or participatory appropriation phase, individuals transform their understanding of the previous two stages to the new and novel contexts (Rogoff, 2003). In contrast to the transmission models of acquisition which are based on theoretical notions of learning as a product of acquisition (Giaconia \& Hedges, 1982; Greene, 1986), the participatory appropriation suggested by Rogoff focuses on person's practicing in an activity in a dynamic, cyclical never-ending process. In other words, appropriation is synonymous with internalization and transformation of new input. Such perception of appropriation results from a person's own participation in an activity, not to his or her internalization of an external event or technique (Rogoff, 1995, 2003).

Despite frequent claims on the effectives of replacing everyday concepts of inservice English teachers with the scientific ones which are derived from the tenets of sociocultural theory to language learning and teaching, no research, to the best of the researchers' knowledge has been conducted on the issue in the EFL context of Iran. Therefore, inspired by the model of development on three planes by Rogoff $(1995,2003)$, the notion of peripheral participation (Lave \& Wenger, 1991 ) within an already configured system of activity, and also the community-oflearners model of education ( Brown \& Campion, 1990; Newman, Griffin, \& Cole, 1989; Tharp \& Gallimore, 1988, among others) which sees active collaboration of the learners and experts as necessary, the researchers aimed at conceptual development of the two teachers regarding replacing their present 
everyday concepts of grammar teaching with the main focus on correctness and accuracy with the socio-culturally oriented view which prioritize appropriate scaffolding, peripheral-to-full participation, and proper appropriation.

Therefore, in line with Johnson and Golombek $(2011,2015)$ who see it as the responsibility of second language teacher education, SLTE, to present relevant scientific concepts to teachers in ways that bring these concepts to bear on concrete practical activity, the researchers conducted the present study which aimed at tracing and understanding present, every day, conceptual thinking of two Iranian EFL teachers regarding their grammatical practices. Then, through raising awareness of social nature of language and learning, and intervention through critical reflection in their ongoing classroom practices tried to support and enhance their professional development regarding teaching grammar through mediation on three planes of grammatical apprenticeship, guided grammatical participation, and participatory grammatical appropriation in the framework of the classroom.

\section{Methodology}

\section{Participants}

Participants of the present study were two Iranian female EFL teachers (with pseudonyms Sara and Tara) who were teaching in Language Teaching Institutes in Kermanshah Province, Iran. Both of them were holding their BA in TEFL at the time of the study. Sara and Tara had 8 and 5 years of experience of teaching in Foreign Language Institutes respectively. Both of them expressed willingness to participate in the study since they believed that the study would contribute to their professional practice. Both of them were native speakers of Persian.

\section{Design, data collection, and procedure}

Based on the nature of the required data and the research questions of the study, the present study, which was an interventionist case study, gave priority to a qualitative approach for data collection and analysis. According to Crotty, the point of departure for much research is the identification of a question or problem (Croty, 2003). He also argues that there should be coherence between the epistemological stance invoked and the methodological approach adopted that the researcher needs to provide in his/her justification (Crotty, 2003). Also, it is stressed in the literature that, in the post-paradigm war of pragmatism, it is the 
research question that is the most determinative in the research design (Bryman, 2008; Stevens, 2009). Furthermore, regarding the perspective taken in his study, Robson(2002) asserts that the detailed study of one particular situation or "case" is the approach that has been pursued in the majority of sociocultural studies of L2 learning. Besides, since the main purpose of the study is to promote change (Robson, 2002), the overall design of the study is action research. Cohen, Manion and Morrison (2000) allow for collaborative researcher - teacher models of Action Research, stressing its core purpose of identifying, understanding, and resolving problems in a specific teaching and learning context with a view to improving that specific situation. According to McNiff, Lomas and Whiehead (1996), the key emphasis is intervention for improvement at a local level in most models of Action research. After all, Bassey re-conceptualizes case study research within educational settings and includes a model of Action Research case study, which is carried out with a view to making beneficial changes to practice (Bassey, 1999). Therefore, the study is an action research case study which aims at reconceptualizing grammar teaching practice of two English teachers.

Data collected for the study were of the following types. 1) Two audiorecorded semis-structured interviews 2) six two-hour dialogic workshops 3) six one-hour-and-half video-recording of each class, with the interval of every two weeks, roughly taking three months, and 4) six one-hour video-recording of the teachers' critical reflection sessions. However, the main data which contributed to answering the questions were the semi-structured interviews and second, fourth and sixth video-recorded critical reflection sessions. The main reason behind choosing every other critical reflection session data was to save space.

The first semi-structured interview was conducted before awareness-raising workshops to elicit and verbalize the current view of teachers on language, learning, grammar, and how to teach grammar. The second interview was conducted after the workshop sessions for two purposes: first, to see whether teachers' attitude regarding language, teaching and grammar has changed, and second, to see whether the participating teachers embrace the participatory model adopted from Rogoff's model of development for their grammar teaching. They were asked, for example, whether they see the model to be effective in their grammar classes. They were also asked to describe examples of situations from their experience in which they had worked with students based on the model. The 
interview sessions lasted about 45 minutes, and they were audio-recorded. Then, they were transcribed fully for follow-up analysis.

The second type of data which aimed at raising awareness of the participating teachers on the nature of language, learning, and grammar teaching from a sociocultural point of view was related to workshop sessions. Regarding the workshop sessions, first teachers were dialogically engaged with one of the researchers in six two-hour workshops in which they dialogically mediated on the new approaches to language and teaching rooted in the tenets of sociocultural theory to teacher education. The materials for the workshops were taken from Johnson (2009) and also Rogoff's (2003) three-plane model for mediational development. Before each workshop, the participants were required to study the section of the book by Johnson (2009) and article by Rogoff (2003) which were going to be used as the main tool for awareness-raising during the workshop sessions.

More than five years of co-working with the teachers gave the insight to one of the researchers that they held a positivistic approach to language teaching in general and grammar teaching in particular, the point which always bothered the researcher who was working as the supervisor of the English Teaching Institute where the two teachers were teaching. Also, the contents of the first semistructured interview manifested this fact. Therefore, the first two workshop sessions were devoted to changing their attitude toward what language is, what learning is, and how language is taught from a socio-cultural perspective. The third workshop was devoted to the dialogic mediation on the idea that teachers are learners of teaching not all-knower of the content knowledge to make them ready for embracing the conceptual thinking which required the teachers to be facilitators and guides than transmitters. During the fourth workshop, the mediation was on the notion of language as a social practice to make teachers aware of the communicative nature of language. The two last workshop sessions were devoted to the application of the three-plane model of development: apprenticeship, guided participation, and participatory appropriation introduced by Rogoff (2003) and how to adopt it to grammar-teaching classes.

Third, following the workshop sessions, with an interval of a week, the classes started. The classes were grammar classes for elementary EFL learners. Each teacher videotaped her class with the interval of every two weeks for 3 months, 6 videotaped sessions for each class. 
Fourth, each videotaped class was critically reflected on by the researcher as a mentor in presence of the teachers. The same as semi-structured interviews, the reaction of the participating teachers during practicum sessions were videorecorded and transcribed for follow-up analysis. The critical reflection sessions were held one day after the video-recording so that teachers have a fresh memory of what was going on in their classes.

For the readers to depict the data collection procedure more clearly, the chronological timeline of different procedures, the date and the purpose is given in the following table.

\section{Table1}

Timeline of the Study

\begin{tabular}{|c|c|c|}
\hline Date & Event & Purpose \\
\hline November $10^{\text {th }}, 2014$ & 1st interview & $\begin{array}{l}\text { To elicit and verbalize the current view } \\
\text { of teachers }\end{array}$ \\
\hline November $17^{\text {th }}, 2014$ & $\begin{array}{l}1 \text { st workshop } \\
\text { session }\end{array}$ & $\begin{array}{l}\text { Mediating on nature of language, } \\
\text { learning and teaching from a socio- } \\
\text { cultural perspective }\end{array}$ \\
\hline November $24^{\text {th }}, 2014$ & $\begin{array}{l}2^{\text {nd }} \text { workshop } \\
\text { session }\end{array}$ & $\begin{array}{l}\text { Mediating on nature of language, } \\
\text { learning and teaching from a socio- } \\
\text { cultural perspective }\end{array}$ \\
\hline December 1st, 2014 & $\begin{array}{l}3^{\text {rd }} \text { workshop } \\
\text { session }\end{array}$ & $\begin{array}{l}\text { Mediating on the issue that teachers are } \\
\text { learners of teaching not knowers of } \\
\text { content knowledge }\end{array}$ \\
\hline December $8^{\text {th }}, 2014$ & $\begin{array}{l}4^{\text {st }} \quad \text { workshop } \\
\text { session }\end{array}$ & $\begin{array}{l}\text { Mediating on the social nature and } \\
\text { communicative nature of language }\end{array}$ \\
\hline December $15^{\text {th }}, 2014$ & $5^{\text {nd }} \quad$ workshop & $\begin{array}{l}\text { Mediating on the three-plane model of } \\
\text { development }\end{array}$ \\
\hline
\end{tabular}




\begin{tabular}{|c|c|c|}
\hline & session & \\
\hline December 22nd, 2014 & $\begin{array}{l}6^{\text {th }} \text { workshop } \\
\text { session }\end{array}$ & $\begin{array}{l}\text { Mediating on the three-plane model of } \\
\text { development }\end{array}$ \\
\hline December $29^{\text {th }}, 2014$ & $2^{\text {nd }}$ interview & $\begin{array}{l}\text { To elicit and verbalize the after- } \\
\text { workshop view of teachers }\end{array}$ \\
\hline January $6^{\text {th }}, 2015$ & $1^{\text {st }}$ videotaping & $\begin{array}{l}\text { Videotaping after-workshop practice of } \\
\text { teachers }\end{array}$ \\
\hline January $7^{\text {th }}, 2015$ & $\begin{array}{l}1^{\text {st }} \text { critical } \\
\text { reflection }\end{array}$ & $\begin{array}{l}\text { To elicit the teachers' emergent } \\
\text { thinking }\end{array}$ \\
\hline January $20^{\text {th }}, 2015$ & $2^{\text {st }}$ videotaping & $\begin{array}{l}\text { Videotaping after-workshop practice of } \\
\text { teachers }\end{array}$ \\
\hline January $21^{\text {st }}, 2015$ & $\begin{array}{l}2^{\text {nd }} \text { critical } \\
\text { reflection }\end{array}$ & $\begin{array}{l}\text { To elicit the teachers' emergent } \\
\text { thinking }\end{array}$ \\
\hline February $3^{\text {rd }}, 2015$ & $3^{\text {rd }}$ videotaping & $\begin{array}{l}\text { Videotaping after-workshop practice of } \\
\text { teachers }\end{array}$ \\
\hline January $4^{\text {th }}, 2015$ & $\begin{array}{l}3^{\text {rd }} \text { critical } \\
\text { reflection }\end{array}$ & $\begin{array}{l}\text { To elicit the teachers' emergen } \\
\text { thinking }\end{array}$ \\
\hline February $17^{\text {th }}, 2015$ & $4^{\text {th }}$ videotaping & $\begin{array}{l}\text { Videotaping after-workshop practice of } \\
\text { teachers }\end{array}$ \\
\hline February $18^{\text {th }}, 2015$ & $\begin{array}{l}\text { 4th critical } \\
\text { reflection }\end{array}$ & $\begin{array}{l}\text { To elicit the teachers' emergen } \\
\text { thinking }\end{array}$ \\
\hline March $1^{\text {st }}, 2015$ & $5^{\text {th }}$ videotaping & $\begin{array}{l}\text { Videotaping after-workshop practice of } \\
\text { teachers }\end{array}$ \\
\hline March $2^{\text {nd }}, 2015$ & $\begin{array}{l}\text { 5th critical } \\
\text { reflection }\end{array}$ & $\begin{array}{l}\text { To elicit the teachers' emergen } \\
\text { thinking }\end{array}$ \\
\hline March $15^{\text {th }}, 2015$ & $6^{\text {th }}$ videotaping & $\begin{array}{l}\text { Videotaping after-workshop practice of } \\
\text { teachers }\end{array}$ \\
\hline March $16^{\text {th }}, 2015$ & $\begin{array}{l}\text { 6th critical } \\
\text { reflection }\end{array}$ & $\begin{array}{l}\text { To elicit the teachers' emergent } \\
\text { thinking }\end{array}$ \\
\hline
\end{tabular}


Finally, both recordings of teachers' practices during critical reflection sessions on their classroom practice, and transcripts of semi-structured interviews were analyzed using Hatch's (2002) procedure for interpretive analysis to identify emerging patterns in the data. This procedure involves recording ideas and impressions in the form of research "memos" that are subsequently studied to identify emerging interpretations. Finally, these interpretations are carried back to the data to ensure that they are supported and to make further refinements. However, to save space, just a representative sample of the transcribed recordings is presented here. The words used by the participating teachers to express ideas that became focal points of the analysis appear in italics in the excerpts from critical reflection sessions.

\section{Data Analysis and Results}

\section{Understanding present thinking of teachers}

To elicit present thinking of the participating teachers regarding language, grammar and its teaching, they were asked to reflect on their present views through the first semi-structured interview. In their reactions, despite some implicit reference to the importance of grammar in language classes which in fact originated from their everyday concepts, no explicit traces of definitions or explanations related to concept under investigation- grammatical development on three planes- and the related socio-cultural concepts were found in the written narratives. An excerpt of Tara's interview is presented below.

Interview I (Tara): ' 'language is a vehicle for communication... Of course, that is one of the tools for communication beside other tools. A successful teacher must have her students use grammar correctly with no mistakes before they leave the class. The students must be very careful and the teacher must have the students' attention to make them avoid from mistakes. For me, grammatical accuracy is the most important, because if students talk grammatically wrong it is funny for the surrounding people. Pronunciation is very important for me. I must prove them in class that what I say is very important for them.... I must have the attention of students all the time ... If students do not obey what I tell them, they won't succeed as I want. I have never let my students make mistakes. I always prove myself and my position 
to my students from the very beginning ... That is awful if they have grammar lapses because such lapses will remain inside their head forever'.

In her interview, Tara, besides believing that language is for communication, sees grammatical accuracy as a very important component for success. Reference to such categories as grammatical accuracy, not making mistakes, awful grammar lapses, and avoiding mistakes emerged times and again during the first interview which possibly show that Tara is not familiar with the social nature of the language although she believes that language is for communication, a common belief for all. As for the teaching, she thinks that she is all knower and all that students need to do is to obey what she orders since she believes what she thinks and believes is the best.

Interview I (Sara): 'Language is for everyday communication outside the class. Teachers must have strict control over the classroom behavior to make students correct speakers and prepare them for communication in their life events. They don't have to let their students make mistakes. I see any mistake, especially grammatical mistakes of the students as the teacher's failure. Teachers must all the time use correct examples in their class. I explicitly dictate to my students the grammatical points and want them to use them in correct examples".

The same as Tara, Sara believes that language is for communication. That is, she implicitly believes that language is of a social nature but sticks to accuracy and exerts strict control over the classroom behavior for her success to come about especially in grammar. Her constant reference to accuracy, correct examples, correct speakers, seeing grammatical mistakes as teacher's failure might show that she is more concerned with accurate and controlled use of the language. However, to save space, just an excerpt of Sara's transcribed reactions was presented. In a nutshell, before the conceptual development of teachers started, many instances of concepts of correctness, accuracy, without mistakes, grammatical lapses and the like were found in their interviews which might show that both Tara and Sara embraced an atomistic, positivistic epistemology to grammar teaching at the time of the interview.

In this phase of the study, the teacher educator attempted to recognize the outer limits of teachers' zone of proximal development (ZPD). This process begins, typically, by encouraging teachers to verbalize their current understandings of 
whatever concept, skill, or disposition which is the focus of study (Johnson \& Golombek, 2011). According to Johnson and Golombek (2011), once teachers' current state of cognitive development becomes explicit, it becomes open to dialogic mediation.

\section{Development of conceptual thinking (preliminary steps)}

If we embrace a sociocultural perspective, the steps of L2 teacher education, whether in the form of workshops, seminars, or teacher-initiated inquiry, must have at their core opportunities for dialogic mediation, scaffolded learning, and assisted performance as teachers participate in and learn about some relevant aspects of their teaching (Grimett, 2014; Johnson, 2009; Johnson, \& Golombek, 2011). Vygotskian sociocultural theory argues that there is a dialectic relationship between every day and scientific concepts. Inspired by Vygotsky's ideas, Johnson (2009) believes that the aim of teacher education, therefore, is to move teachers beyond these everyday concepts by introducing them to scientific concepts - concepts that have already been identified and formulated by one's professional discourse community, defined in formal theories, and acquired through formal instruction.

In this section of the study, findings from the second semi- structured interview data which was conducted following the workshop sessions are discussed concerning the preliminary steps taken toward the development of concept of grammatical -mediation- on three- related- planes of grammatical apprenticeship, guided grammatical participation, participatory grammatical appropriation and the related socio-cultural concepts. The initial steps of development were characterized by imitation and the formulation of rationales or motives for learning and applying the new concepts. The following data from the second interview shows how participating teachers communicated their emerging understanding of the concept of grammatical- development-on-three-interrelated-planes and the related sociocultural concepts.

Interview II (Tara): 'Before, I thought I must be careful so that my learners are as accurate as possible when they say or write something. In fact I thought it was a weak point for the teacher if learners have grammatical mistakes. Before I dictated to the students what a certain grammatical point was good for and explicitly taught them its use. ... My 
biggest mistake was that I did not let the students express themselves. Especially for elementary levels, I thought they were low-level students and they did not know many things, so I must talk all the time. I even did not give them the opportunity to express themselves so that I realized whether they had understood the points. But now I have changed. Now I think it is not possible for us to learn something free from mistakes. Even me, I have made many mistakes before I learnt something. Context must be provided for the learner continuously both inside and outside the class. I think I must encourage the students participate from the very beginning of a grammatical activity. The more they participate, the more they realize how they should use a certain grammatical point. We must not expect them learn something in a short time. Little by little, and by logical help and engaging them in activities, everything will be ok. Teacher domination classes and quick interruption to correct a mistake is the worst point I have been aware of. The teaching process must be through proper scaffolding".

The interview by Tara shows how she is somehow not satisfied with her classroom practices before the workshop sessions. As she claims, her past concepts such as accurate use of grammar, explicit grammar teaching, no grammatical mistakes, has been replaced by such concepts as not possible to learn free from mistakes, continuous provision of context, more participation, and engaging in activities. This might be due to the conflict between her previous everyday concepts and present emerging scientific concepts regarding how to teach. Also, as the following data from the interview by Sara show, she has the same attitudes as Tara.

Interview II (Sara): "' I am really not satisfied now with the way I taught grammar in my classes before. I should not have thought that grammatical accuracy from the very beginning of teaching it would happen. I should not have dictated to the students to memorize the grammatical structures and to use them in their speaking and writing. I have in fact wanted my students to hunt without teaching them how to hunt. I am always challenging myself over why I didn't let my students give out what they had in their existence so that I could have helped them cope with their existing problems. I think I am not the same person as before the workshop regarding my classes. I must help my students use the structural points in their proper context. Language is for social interaction with others and its handling can happen through 
actively involving the learners in tasks which are similar to social activities. If learners do not participate in socially designed tasks, they can't use the language properly in real situations. I think I should not have made so many unnecessary corrections in my previous classes. Instead, I should have increased my learners' participation and have assisted them in challenging situations instead of interrupting them'.

Frequent emergence of such expressions as " I shouldn't have ....", " I could have ..." ", might suggest that she is in a state of conflict which has been created as a result of her being aware of new scientific concepts. It seems as if she is mentally wrestling with her conception of what it means to be a successful L2 teacher.

The participating teachers, besides blending their understanding of the new concepts to their prior experiences and everyday concepts, without being explicitly asked to do so, also linked the concepts with rationales for learning it and applying it to their teaching practice in their second interviews.

Interview II (Tara) ' 'I think that many teachers are familiar with the terms such as communicative classes, teaching communicatively, teaching real life tasks, but don't know how to put their ideas into practice. I think we need to train teachers on how to teach. Teachers know grammatical structures in English but many of them might not know how to put them into practice. I believe that we need to make teachers aware of the reality".

Tara seems to believe that teachers are superficially familiar with the communicative nature of language and teaching. All she is possibly worried about is training teachers to learn how to put this into practice. This is also evident in Sara's words as the following excerpt indicates.

Interview II (Sara) "I think the topics of social practice, classroom participation, learner engagement, assistance, classroom interaction, communicative teaching of grammar and the like are just claimed both by theoreticians and teachers. I believe that teachers must make students aware of such topics that need to be discussed in second language classrooms. I think that I am lucky to have been given awareness on some topics, but this need to be done for all teachers." 
The remarks above, besides expressing rationales to frame and direct conceptual development and learning, reflect the goal-oriented nature of human activity, which is according to Lantolf \& Thorne ( 2006) the key element of Sociocultural theory. Seen through the glasses of sociocultural perspectives to teacher education, the potential for teacher learning occurs when feeling of tension between cognition and emotion can sometimes create a space for learning (Golombek \& Johnson, 2004). However, the main purpose of sociocultural theory to teacher education, as mentioned earlier, is not mere verbalizing of alreadyemerged scientific concepts in the literature. The main objective is to replace the present everyday concepts of teachers through re-conceptualizing their present thinking on the issue in a way that the re-conceptualized concepts become concretized tools under the command of the teachers (Vygotsky, 1978; Johnson, 2009; Johnson \& Golombek, 2011). Consequently, the teacher re-contextualizes his/her teaching practice, resorting to the new functional tools. For this to come about successfully, according to Walsh (2011), constant critical reflection on the teacher's emerging behavior is very important. In line with this, the six videotaped classroom behaviors of each teacher were reflected on and their reactions were video-recorded for follow-up analysis. Of the six video-recorded critical reflections for each teacher, however, three were transcribed, the second, the fourth, and the sixth.

\section{Concretizing the concepts in teachers' classroom behavior through critical reflection}

This section presents findings based on the data gathered from the critical reflections on the teachers' classroom behavior in order to investigate concept development beyond the initial stages discussed above in relation to the workshops. Of the six classroom video recordings for each class, three sessions for each teacher were reviewed and critically reflected on. The recordings related to each session were reviewed and reflected on the day after data recording so that participating teachers were given awareness of their classroom practice on the spot. Through self-reports of their classroom behavior, the participating EFL teachers' reactions offered insights into how the participating teachers linked their conceptual understanding of grammatical teaching on three planes of development to their classroom practices. This is in line with the tenets of Sociocultural theory to teacher development which posits that through gaining psychological control over recently emerging scientific concepts, in- 
service teachers can envision alternative modes of educational practice, and cope with the challenges of making the final step from thinking through concepts to acting through them.

The first critical reflection addressed teaching simple present in Tara's class where she continuously interrupted the participating students to check their grammatical mistakes especially third person singular (s). On being asked about the situation she reacted:

Critical reflection I (Tara): ''I should not have had that much correction. I think I should have first provided them with some real life examples, and then have wanted them to participate in discussions guided by me as the more knower. I don't know why I interrupt that much. I think I must assist them to participate, to express real life instances about themselves. I need to be consciously aware of my classroom behavior. I think these learners need to be appropriately guided. I think I should have helped them shape their contributions. If I help them participate in the classroom talk, I think they would better learn when to use present simple. They cannot learn the present simple structure all in one session, so why am I constantly checking, and interrupting them, although I have recently realized that structures are best configured through constant participation. Grammatical structures are properly learned and reused in case they become appropriate tools for subsequent participation".

To save space, and avoid circumlocutions, the same as transcriptions of workshops, only a small portion of the reactions of the teachers in each session was included. However, the overall transcribed data show that many instances of categories emerged. During the preliminary classroom sessions, on being critically reflected on her behavior, Tara seems to confess that she has too many corrections, interruptions, and constant checking. Also she claims that she should have had more appropriation, guiding, and contribution. This might be due to the fact that the emerging scientific concepts have not yet been the psychological tools under the control of Tara as the agent of participation. This is somehow evident in her following reaction to the question why she thinks proper participation is better than constant correction. 
Critical reflection I (Tara): "I have had constant checking for years with no fruitful results. I have always thought students must not commit any mistakes when they speak or write, but despite many interruptions and corrections on my part, they still commit silly mistakes both when they speak and when they write. The funny side of the issue is that I check a grammatical mistake today very explicitly but the learner commits it the other day. ... Anyhow, I must change my classroom behavior. Recently I visit people from other countries who commit those silly mistakes, but they can communicate very intelligibly. My learners, despite my sensitivity to their mistakes, are not as communicative as them."

The constant use of "I shouldn't have .......", I don't know why .... “, I must ....", " I think I should have" in her first excerpt and also " I have always thought ..." ", in the second one can be interpreted as sign of conflict between her true ingrained identity regarding her present classroom behavior and her want-to-be one.

The first session of classroom reflection by Sara focused on present perfect. In her attempts, the same as Tara, her main objective was to elicit correct samples of present perfect from the learners. There were a great number of corrections, interruptions, and explanations during the time she focused on present perfect. On being asked about her reactions in class, she said:

Critical reflection I (Sara): 'I am doing my best to help my students give out correct samples although I know that they won't be able to use the pattern correctly in one session. I think I am stopping my learners too many. I know that too much focus on correction won't result in good ends, but I think I do it unconsciously. I will try not to do it in my next sessions. I think all that these learners need to help them participate in the classroom turns. Of course providing appropriate examples in real life tasks is necessary so that they become familiar with appropriate forms. After that I think I must encourage their participation by providing appropriate situations. For example, instead of correcting them, I could have helped them talk about their experiences, real life experiences. I think the book is balmy, too, Why have not the authors provided the learners with the situations which requires them to participate both orally and written. These fragmented examples won't do well for the learners. They can't appropriately apply the present 
perfect in later-on situations even with guidance. I think I must change my classroom practice'.

Upon critical reflection on Sara's first classroom behavior, she also admits that her classroom interactional practice includes many cases of stopping, and correcting, while she believes that too much focus on correction won't result in good results. She also believes that she must help the learners by providing appropriate situations for participation. This might show that, the same as Tara, Sara has faced a conflictual issue as to her past experience in teaching practices and her emerging ideologies and conceptions. This can be inferred from her reaction to the question why she thinks she must have provided better opportunities for learners' participation.

Critical reflection I (Sara): "I am not an inexperienced teacher. Five years of teaching has given me the clue that my learners, also the learners of my colleagues, are not communicative. When they face a real life situation, they can't be what I wish them to be. I think I have always focused on checking and correcting uselessly. Now that my students still commit many grammatical mistakes despite my everlasting corrections, I think I will change my way of teaching. You see I focused on correcting them times and again during the teaching time, but they still committed silly mistakes not just in dealing with present perfect but with the former structures such as present simple, continuous, past perfect. I need to provide better opportunities for participation, and for appropriation of grammatical structures not for their correction."

Sara believes that her constant correcting and checking has not been very satisfactory. So, she claims that she needs to change her participatory classroom structure. This might show that Sara has familiarity with the new concepts and somehow believes in acting upon them, but the new concepts might not have been psychological tools under her unconscious control.

Despite dialogic mediation on the concepts of language, teaching, learning form a sociocultural perspective, and Rogoff's (2003) model for appropriation during six workshops, the participating teachers did not seem to act, albeit thought, according to their new concepts in the classroom context due to unarticulated, yet deeply 
ingrained, notions about what language is, how it is learned, and how it should be taught (Freeman, 2002). However, after awareness-raising sessions through critical reflection on their subsequent teaching practices by the mentor teacher, their acting somehow coordinated with their new scientific beliefs halfway through the recording sessions. This seems to be evident in the second critical reflection sessions performed on their fourth video-recorded classes.

The second classroom reflection of Tara addressed teaching adverbial clauses of future time. During this session, Tara did not seem to interrupt the participating learners to check their grammatical mistakes very often especially when they used the adverbial clauses of time inappropriately. On being asked about her reactions, she remarked:

Critical reflection II (Tara): 'I think I am doing much better regarding my interruptions. Now I know what I should do to actively engage my learners. I think presenting models appropriately at the presentation phase is rewarding for follow up activities. Learning a new grammatical structure is like learning a craft at the beginning. If you present good real-life examples, it is as if you have given your learners their food of thought. ..... Before ,I didn't pay attention to guiding my students through participating in social interaction with the focus on new grammatical points. All my concern was not to allow my learners commit grammatical mistakes of any type, but this in turn could harm the participatory organization of the classroom. The learners can talk about their future and future wishes, if they are guided at the beginning of their introduction to future adverbial clauses, the same as what my students do. ..... For better appropriation of the future-clauses, I wanted my students to write about their future expectations and wishes, so that they can appropriate the grammatical structure for future uses in other contexts. I wish I had realized how to teach through actively engaging my learners in social participation earlier than this. ... I have missed many opportunities in this regard before. I don't have to think of interrupting for the purpose of checking. Instead, I have to think of assisting, guiding in participatory cases, and appropriating the structures".

In the second critical reflection session, Tara seems to be more satisfactory with her behavior. She refers to "not allowing the learners commit mistakes", and "interrupting for the sake of checking" as negative classroom factors. She seems to be more in line with actively engaging the learners, admiring 
participation, better appropriation, assisting, and guiding, which are all signs of socio-culturally oriented approaches to learning. She also seems to believe that the past classroom behavior was unlikely as she didn't pay much attention to guiding, assistance, and active engagement of the learners before.

The second classroom reflection of Sara addressed teaching unreal and imaginative conditions. Sara, also, had cut down on the number of interruptions and over-dominations compared to the first critical reflection session. On being asked about the reactions, she said:

Critical reflection II (Sara): "' I enjoy it when I see my learners are getting more involved in this session. In fact, I have never, during my teaching experience, been able to teach unreal conditions so efficiently. You can see how my learners are well expressing themselves and state their wishes and imaginations. This is all English teachers are following. All they need to be told to is presenting several good examples in contextualized dyads. Then they themselves know how to lead the way. ..... In this session, I am not a presenter. Instead, I am a participant of a higher position who is helping others to participate in interactions the same as what a mother does for a child. ... Now I am thinking of grammar correction as a negative word, but I think of grammar participation as a better replacement. I think the learners can use the structure in future contexts if enough appropriation is achieved. I think I must think of appropriating the structure much better in follow-up instances, but this won't happen overnight, so grammar correction will lead to nowhere'.

Upon the second critical reflections by Sara, the same as Tara, she believed that her learners are more involved, express themselves well, and participate more efficiently. She claims that grammar correction is a negative act while grammar appropriation is a better replacement. Many instances of such categories were found in her second critical reflection session, a small excerpt of it was presented here, however.

The data for the second critical reflection sessions of both teachers show that the participating teachers are starting to think in about new concepts and they themselves can see that they are acting according to underpinnings of their new concepts. Their comments on their own practice possibly suggest a deepening 
understanding of appropriation on three planes in that they constantly refer to the power of appropriation through participation as the leading force in their classes. This is in line with ideas put forward by Johnson and Golombek (2011) who believe that sociocultural research to teacher education should have the potential to expose the discursive practices that shape teachers' knowing, thinking, and doing and provide us with a window into how the use of deliberate and strategic mediational means can help to create opportunities for teachers to move toward more theoretically and pedagogically sound instructional practices within the setting and circumstances of their work (Johnson \& Golombek, 2011, p. xii).

The third critical reflection in Tara's class addressed teaching past wishes and regrets. The main focus during the class was on how to regret over missed opportunities with grammatical structures such as "I wish + past perfect structures", " third conditional sentences", " It was time + past simple structures", and "If only + past simple structures". On being asked about the situation, she reacted:

Critical reflection III (Tara): 'I really enjoy the way I am involving the learners in participatory moments. That's a new world in old context. I don't see it necessary to stop my students because they are, I think, performing well through participation. .... I know believe that grammar must be taught in three different phases: giving the real-life sample of the grammatical patterns, helping the learners apply the samples in their classroom participatory tasks, and trying to appropriate the structures through constant participation in follow-up contexts. ... It has become my food of thought to think of assistance, participation, appropriation ...... I don't want to think of my past beliefs regarding teaching grammar, the notions such as accuracy, explanation, correct examples, .... No, no, no, never ever. I am trying to totally force them out of my mind. .... Even my postures and gazes seem to have changed. ... That is really a new classroom context with new participation models".

Tara referred to such expressions as performing through participation, real life samples, participatory tasks, and participation in follow-up contexts as her food of thought. This might be because she has already replaced her old concepts with the new ones as she claims. Using expressions such as "a new world in an old context" for several times can possibly indicate that she is 
thinking of a new context. This is possibly well-addressed in the following excerpt.

Critical reflection III (Tara): "Teacher initiations and questioning does not provide a beneficial learning context for the learners. I am not satisfied with what I have performed in the class before. In any classroom communication, a balanced interactional relationship is necessary. Time has changed. I think the communicative structure of my class has changed. I will never be the same teacher as before. I really enjoy the way my learners participate in the appropriation of new structures."

Tara seems to confess that her classroom participatory structure has changed. Also, it seems that she enjoys the way the learners participate and appropriate the newly introduced items.

The third critical reflection for Sara's class was on teaching "to infinitives" of all kinds: simple, continuous, perfect, and perfect continuous. She, through constant engaging of her learners in real-life samples which she had provided in advanced, supported the participation of her learners by providing them with appropriate support. On being asked about the situation, she remarked.

Critical reflection III (Sara): "You see I am doing my best not to interrupt, not to correct because I believe that such classroom participation is all that leads to success. ... The art of the teacher is providing for appropriate participation by appropriate assistance. Interruption and correction lead to nowhere. I do not want to think of them anymore. During my past years of teaching, I think I have been an impediment to my students' success. In fact $I$ am living in a new era of my profession. ... I think I have become a good craftsman for my apprentices. Look at the way I participate and help my learners participate in the classroom tasks. ... I think I have changed overall'’.

As her third critical reflection session shows, Sara also seems to have changed her mind regarding the participatory structure of her classroom. Using such expressions as no interruption, providing for appropriate assistance and participation, and no correction possibly shows that she has changed her attitude towards what the classroom interactional behavior should be like. This 
was constantly observed in her wording while she was commenting on her classroom behavior.

\section{Discussion}

The findings of the present study deserve consideration from several regards. First, the findings related to the workshop sessions reveal that the primary steps toward concept development which occurred through awareness-raising included imitation of expressions having been dialogically discussed in the workshop sessions. The participating teachers most probably imitated what they had been presented to and discussed with them regarding the nature of language, learning, grammar, and appropriation through participation albeit through implicit reference to such concepts. This is in line with Johnson (2009), Johnson \& Golombek (2011) and Grimmet (2014) who argue that the teachers' teaching practice is not just abstracted from theories pinned down in textbooks. It also emerges out of a dialogic transformative process (Johnson, 2009) of reviewing, reconsidering, reorganizing and re-contextualizing their lived experiences through the theoretical constructs and discourses that are universally recognized and valued within their professional community of practice. Holding conferences, seminars, workshops, and the like might just lead to verbalism of already-investigated scientific concepts. This is not fruitful, as this verbalism might not contribute to changing negative features of teachers' interactional architecture of the classroom (Seedhouse, 2004). The present research showed that through bringing the in-service teachers' teaching conception into their awareness and constant critical reflection on their classroom behavior, teacher educators can reshape the interactional strategies of the teachers.

As Johnson (2009) puts it, everyday concepts are formed during extended periods of concrete practical experiences in the cultural environment of schooling and/or language learning experiences in the everyday world (pp.1-2). This kind of empirical learning, resulting in everyday concepts, however, often leads to misconceptions about language, learning and language teaching. Therefore, blending everyday concepts rooted in the prior experience of the participating teachers with their emerging scientific concepts can be seen as an important aspect of development in that it represents the dialectical unity of one's current level of development and one's potential level, known as ZPD in Vygotsky's terminology.

The mediation through awareness-raising conducted in workshop sessions by means of materials from Johnson (2009) possibly made participating teachers 
capable for expressing ideas related to teaching grammar on three planes through proper assistance, participation, and collaboration. Such remarks could have been the result of blending past ideas and experiences of everyday and scientific concepts. This act of connecting teaching grammatical structures on three planes to other experiences and concepts can mark an important preliminary step in concept development by creating a ZPD for new ways of thinking about L2 education and concrete action resulted from ingraining of scientific concepts as new psychological tools.

According to the proponents of sociocultural theory in teacher education (e.g. Freeman, 2002; Freeman \& Johnson, 1998, 2005; Freeman \& Richards, 1996; Johnson, 2009; Johnson \& Golombek, 2011; Grimmet, 2014), theoretical concepts offer new ways of understanding the world by going beyond what we know from our everyday experiences. This was evident in the responses to the critical reflections on the participating teachers' classroom behavior. They constantly confessed that they had changed their classroom practice, rejecting their previous teaching conceptions such as correctness, accuracy, interruption for correction, explicit explanation and the like, and praising the newly emerged concepts as assistance, participation, appropriation and the like.

The reactions on part of the participating teachers on the value of emerging concepts especially in the first critical reflection sessions, despite their not being observed in their classroom behavior, seems to provide a rationale for the importance of developing concepts through formal education. According to Davydov (1990), theoretical concepts offer a means of vicariously knowing aspects of the world that cannot be readily observed or things that have not been experienced empirically. However, as the data of the critical reflection sessions reveal, development of concepts might not go through a straightforward path. As Vygotsky puts it, the emerging conceptualization of scientific concepts follows a "twisting path" (Vytogsky, 1987, p. 156) mediated by the previous language learning history which is the result of preconceived notions of teaching from his "apprenticeship of observation" (Lortie, 1975).

Through persistent dialogic mediation and critical reflection on teachers' classroom behavior, it is possible to equip in-service teachers with the new theoretical concepts which in turn relieve them from experience per se by offering 
them new psychological tools (Vygotsky, 1978). As the two participating teachers confessed, the movement beyond direct experience could also make it possible to imagine the world other than it is, and, therefore, to envision new modes of educational practice. In the present study, as the data revealed, learning, thinking in, and acting based on new scientific concepts of apprenticeship, guided participation, and participatory appropriation created a new interactional space in the classroom which both of the participating teachers referred to as 'a new world'. This is in line with what Seedhouse (2004), who claims that, teachers can be seen as the architect of their classroom context in that, they create either constructive or impeding Classroom Interactional Competence (CIC) (Walsh, 2011).

Nonetheless, while the participating teachers confessed that they had changed, fully concrete action directed by new concepts was not explicitly observed in their classroom interactions as they sometimes unconsciously resorted to checking grammatical correctness of their learners. This is in line with what Vygotsky (1987, p. 156) called " twisting path", in which learners alternate between their old and new concepts during their classroom practices. This was in fact evident in the data as they both claimed that they didn't want to think of the old concepts. In other words, old concepts unwantedly came back to them, but they struggled to get released from them. Since bringing a new theoretical concept to concrete action through praxis is an essential final step in full conceptual development, additional attempt is required so that the newly planted concepts become solidified enough and emerge in concrete actions that result in bringing about change in educational practice.

\section{Conclusion}

Thinking through theoretical concepts in teacher education is a rewarding way to alternate classroom practices the way it is believed to be most beneficial. For years, professionals in the field of teacher education have been trying to replace unwanted, possibly wrong ingrained habits of teachers by new theoretical findings, but nothing significant seems to have happened.

In the present study, the difference between what Davydov (1990, p. 270) refers to as " being and coming into being", or what Vygotsky (1987) address it as "twisting path with conflictual moments" and what we, researchers, call it " the journey from accurate acquisition to appropriate participation" through 
transforming related abstract scientific concepts into concrete ones, can be seen in the data of both semi-structured-interviews of the workshop sessions and critical reflections on recorded classroom practices. In both the semi-structured interviews and the critical reflection data, it was revealed that the participating teachers are in struggle with their past experience and practice. That is due to the fact that the participating teachers' reflections and reactions blended elements of their prior perspectives and experiences- their reaction on their present thinking tools- with ideas imitated from the workshop data and critical reflection sessions. This mixing of the past and present experiences signals the rudimentary steps in concept development, thereby shaping a new ZPD which opens a mediational space (Vygotsky, 1987) for the new theoretical concepts to develop.

The second point of notice is the emerging conceptualization of teaching grammar on the three planes of apprenticeship, guided participation, and participatory appropriation. The attempt to inject findings from theoretical linguistics and SLA (Grimmet, 2014; Johnson, 2009; Johnson \& Golombek, 2011) - which are believed to be based on theoretically and pedagogically sound ideasinto teacher education through conducting seminars, workshops, and the like begins to fade as the teacher is not challenged to think about his/her teaching practice. In the present study, the emergence of new conceptualizations of teaching L2 grammar followed a "twisting path" (Vytogsky, 1987, p. 156) and mediated by the participatory teachers' own language learning and teaching history and the new activity systems - workshops and critical reflection sessionsthat constantly created struggle for the participatory teachers' thinking, understanding and acting made the situation different. The teachers themselves claimed that they had reshaped and re-contextualized their teaching practice.

In sum, in line with Lantolf \& Thorne (2006), sound dealing with concepts make it possible for us to share the theoretical accumulated knowledge and gain deeper understanding of related scientific concepts by seeking assistance from professionals without being under pressure to rediscover or experience for ourselves what others have already come to know through their own experience This way, introducing new scientific concepts to in-service- teachers can provide the route for teachers to develop much prior to their own experience which might take years to come about. 


\section{Notes on Contributors}

Saman Ebadi is assistant professor of applied linguistics at Razi University, Kermanshah, Iran. His research interests include sociocultural theory, dynamic assessment, CALL, discourse analysis, and syllabus design. He has published and presented papers in international conferences and journals.

Nouzar Gheisari is a $\mathrm{PhD}$ candidate of TEFL at Razi University of Kermanshah. His research interests include teacher development, sociocultural SLA, classroom talk-in-interaction, and teaching methodology. He has published and presented papers in international conferences and journals.

\section{References}

Bassey, M. (1999). Case study research in educational settings. Buckingham: Open University Press.

Block, D. (2003). The social turn in second language acquisition. Washington, DC: Georgetown University Press.

Britzman, D. P. (1991). Practice makes practice: A critical study of learning to teach. Albany, NY: State University of New York Press.

Brown, A. L., \& Campione, J. C. (1990). Communities of learning and thinking, or a context by any other name. In D. Kuhn (Ed). Developmental perspectives on teaching and learning thinking skills. Contributions to Human Development, 21, 108-126.

Bryman, A. (2008). Social research methods (3rd ed.). Oxford: Oxford University Press.

Burner, J. S. (1983). Child's talk: Learning to use language. New York: Norton.

Cohen, L., Manion, L., \& Morrison, K. (2000). Research Methods in Education (5thed.). London: Routledge Falmer. 
Crotty, M. (2003). The foundations of social research: Meaning and perspective in the research process. Thousand Oaks, CA: SAGE Publications Inc.

Darling-Hammond, L. (2006). Constructing $21^{\text {st }}$-century teacher education. Journal of Teacher Education, 57(3), 300-314.

Davydov, V. V. (1990). Types of generalization in instruction: Logical and psychological problems in the structuring of school curricula. Reston, VA: National Council of Teachersof Mathematics.

Dunn, W. (2011). Working toward social inclusion through concept development in second language teacher education. In Johnson, K.E., \& Golombek, P.R. (Ed), Research on second language teacher education: A sociocultural perspective on professional development (pp. 50-64). Netherland: Sense Publishers.

Freeman, D. (2002). The hidden side of the work: Teacher knowledge and learning to teach. Language Teaching, 35, 1-13.

Freeman, D. (2004). Language, sociocultural theory, and L2 teacher education: Examining the technology of subject matter and the architecture of instruction. In M.R. Hawkins (Ed.) Language learning and teacher education: A sociocultural approach (pp. 167-197). Clevedon: Multilingual Matters.

Freeman, D., \& Richards, J. C. (Eds.) (1996). Teacher learning in language teaching. Cambridge: Cambridge University Press.

Freeman, D., \& Johnson, K. E. (1998). Reconceptualizing the knowledge-base of language teacher education. TESOL Quarterly, 32 (3), 397-417.

Freeman, D. \& Johnson, K. E. (2005). Towards linking teacher knowledge and student learning. In D. J. Tedick (Ed.) Language teacher education: International perspectives on research and practice (pp. 73-95). Mahwah, NJ: Lawrence Erlbaum Associates. 
Giaconia, R. M., \& Hedges, L. V. (1982). Identifying features of effective open education. Review of Educational Research, 52, 579-602.

Golombek, P. R., \& Johnson, K. E. (2004). Narrative inquiry as a mediational space: Examining emotional and cognitive dissonance in second-language teachers' development. Teachers and Teaching: Theory and Practice, 10 (3), 307-327.

Goody, E. N. (1989). Learning, apprenticeship and the division of labor. In M. W. Coy (Ed.), Apprenticeship: From theory to method and back again. Albany, NY: State University of New York Press.

Greene, M. (1986). Philosophy and teaching. In M. C. Wittrock (Ed.), Handbook of research on teaching ( ${ }^{\text {rd }}$ ed.). New York: Macmillan.

Grimmett, P. P. (2009). The best lack all conviction, while the worst are full of passionate intensity. In A. Pitt (Ed.), Key notes in teacher education: CATE invited addresses 2004-2008(pp. 55-77). Ottawa, ON: Canadian Association for Teacher Education.

Grimmet, H. (2014). The practice of teachers' professional development: A cultural- historical approach. Sense Publishers: The Netherland.

Hatch, J. A. (2002). Doing qualitative research in educational settings. Albany, NY: State University of New York Press.

Johnson, K. E. (2006). The sociocultural turn and its challenges for second language teacher education. TESOL Quarterly, 40 (1), 235-257.

Johnson, K. E. (2009). Second language teacher education: A sociocultural perspective. New York: Routledge.

Johnson, K. E., \& Golombek, P. R. (Eds.) (2011). Research on second language teacher education: A sociocultural perspective on professional development. Routlege: New York and London.

Johns, K. E., \& Golombek, P. R.(2015). Mindful L2 teacher education. A sociocultural perspective. Routledge: Amazon. 
Karpov, Y. V. (2003). Vygotsky's doctrine of scientific concepts: Its role for contemporary education. In A. Kozulin, B. Gindis, V. S. Ageyev, \& S. M. Miller (Eds.), Vygotsky' educational theory in cultural context (pp. 65-82). Cambridge, UK: Cambridge University Press.

Kennedy, M. (1999). Ed schools and the problem of knowledge. In J. Rath, \& A. McAninch (Eds.), What counts as knowledge in teacher education? (pp. 29-45). Stamford, CT: Ablex Publishing.

Lantolf, J. P., \& Appel, G. (1994). Theoretical framework: An introduction to Vygotskian approaches to second language research. In J. P. Lantolf \& G. Appel (Eds.), Vygotskian approaches to second language research (pp. 132). Norwood, NJ: Ablex.

Lantolf, J. P., \& Thorne, S. (2006). Sociocultural theory and the genesis of second language development. Oxford: Oxford University Press.

Lave, J., \& Wenger, E. (1991). Situated learning: Legitimate peripheral participation. Cambridge: Cambridge University Press.

Leont'ev, A. N. (1981). The problem of activity in psychology. In J. Wertsch (Ed.) (1990), The concept of activity in Soviet psychology (pp. 37-71). Armonk, NY: M. E. Sharpe, Inc.

Lortie, D. (1975). Schoolteacher: A sociological study. Chicago: University of Chicago Press.

McNiff, J., Lomax, P., \& Whitehead, J. (1996). You and your Action research project. London: Routledge.

Nuttle, J.G. (2005). Pathway to the future? Doing children in the era of New Zealand's early childhood strategic plan. Wellington: Institute for Early Childhood Studies, Vicoria University of Wellington.

Ord, K. (2010). Bodies of knowledge: Early childhood teachers' experience of their initial teacher education program and sense of preparedness for teaching. 
(Unpublished doctoral dissertation). Massey University, Palmerston North, New Zealabd.

Robson, C. (2002). Real world research. Oxford: Blackwell.

Rogoff, B. (1990). Apprenticeship in thinking: Cognitive development in social context. New York: Oxford University Press.

Rogoff, B. (1994). Developing understanding of the idea of communities of learners. Mind, Culture, and Activity, 1, 209-229.

Rogoff, B. (1995). Observing sociocultural activity on three planes: Participatory appropriation, guided participation, and apprenticeship. In J.W. Wertsch, P. delRio, \& A. Avarez (Eds.) Sociocultural studies of mind. Cambridge: Cambridge University Press.

Rogoff, B. (1998). Cognition as a collaborative process. In W. Damon (Series Ed.) \&D. Kuhn \& R.S. Siegler (Vol. Eds.), Cognition, perception and language: Vol. 2. Handbook of Child Psychology (5th ed.). New York: Wiley.

Rogoff, B. (2003). The cultural nature of human development. New York: Oxford University Press.

Rogoff, B., \& Gardner, W. P. (1984). Adult guidance of cognitive development. In B. Rogoff \& J. Lave (Eds.), Everyday cognition: Its development in social context (pp. 95-116). Cambridge, MA: Harvard University Press.

Seedhouse, P. (2004). The interactional architecture of language classroom: A conversation analytic perspective. Oxford: Blackwell.

Shulman, L.S. (1986). Paradigms and research programs in the study of teaching: A contemporary perspective. In M.C. Wittrock (Ed.) Handbook of research on teaching (pp. 3-36). New York: Macmillan.

Stenhouse, L. (1975). An introduction to curriculum research and development. London: Heinemann.

Stevens, J. (2009). Applied multivariate statistics for the social sciences( $5^{\text {th }}$ ed.). Mahwah, NJ:Lawrence Erlbaum. 
Tharp, R. G., \& Gallimore, R. (1988). Rousing minds to life: Teaching, learning, and schooling in social context. Cambridge, UK: Cambridge University Press.

Walberg, H. (1977). Decision and perception: New constructs for research on teaching effects. Cambridge Journal of Education, 7 (1), 12-20.

Walsh, S. (2011). Exploring classroom discourse: Language in action. London: Routledge.

Walsh, S. (2015). Classroom discourse and teacher development. Edinburgh: Edinburgh University Press.

Wertsch, J.V. (1991). Voices of the mind: A sociocultural approach to mediated action. Cambridge, MA: Harvard University Press.

Vygotsky, L. S. (1978). Mind in society: The development of higher psychological processes.

Cambridge, MA: Harvard University Press.

Vygotsky, L. S. (1986). Thought and language. Cambridge, MA: MIT Press. 